\title{
Social disclosures in Russian corporate reporting: successes, failures, directions of development
}

\author{
Olga Efimova*, and Olga Rozhnova \\ Financial University under the Government of the Russian Federation, Leningradskiy prospect, 49, \\ 125993 Moscow, Russia
}

\begin{abstract}
The article examines issues relating to disclosures of social aspects in companies' reports. The conducted study has analyzed financial and corporate reports (integrated, on social responsibility, on sustainable development) of leading Russian metallurgical companies, which consider social impacts as the most significant. The practical part of the research is based on analysis of 42 financial and 37 non-financial reports (including 23 SDR, 12 IR and 2 CSR) of Russian metallurgical companies over 2017-2019 period. In addition, we analyzed the interim financial statements of these companies for 2020. The study of social disclosures was structured into two types of reporting - financial and non-financial. Based on conducted statistical and qualitative analyses, the study offers recommendations on improving logical alignment and quality of disclosures on the social-related aspects. Suggested recommendations aim on increasing validity of investment decisions and making financial market more transparent.
\end{abstract}

\section{Introduction}

The recent years have been showing the trend of investors' increased attention to the social responsibility of business as a factor in its long-term sustainability and, consequently, to social reporting. The emergence of social reporting and its development is associated with the demand on both the investor and the society levels. This trend has acquired particular importance in the context of a pandemic.

The pandemic is believed to have shifted the focus from environmental to social and corporate governance factors. While climate change dominated ESG discussions before 2020 , the pandemic has forced companies to pay special attention to the risks of managing human and social capital.

Different countries have taken unprecedented measures to financially support socially significant companies and to encourage investment in companies with clear social priorities. In its annual Global Risk Report, the World Economic Forum highlighted social risks among the most important ones, including the risks to safety and health protection together with the consequences of digitalization and growing inequality. The pandemic caused a halt in career growth, and / or the uncertainty of its continuation, the need to master digital technologies

\footnotetext{
*Corresponding author: efimova@fa.ru
} 
and remote communication programs which many people find difficult, it blurred the line between working time and rest time; some social groups found themselves under constant control for over 12 hours a day, etc.

It is important to emphasize the existing link between economic, environmental and social problems. Climate change, pollution of the human living environment leads to rapid deterioration in the state of the social sphere. Every consequence of negative changes in the planet's ecological and biological systems has an adverse effect on the physical and psychological-emotional health of the population. It results in the constant risk of social instability and social upheaval, which in turn has serious financial consequences.

The expected result of all the trends was the increased attention of the interested parties to the social aspects of the activities of both individuals and businesses. The topics of social and human capital are highlighted as significant along with financial capital, in the financial and non-financial statements of companies. It is associated with the high importance of this information for strategic decisions including decisions in the investment area.

\section{Review of Prior Literature}

The most active discussions in the study area are dedicated to the following subjects:

- assessment of the impact that social and environmental disclosures has on financial performance [1,2],

- the dependence of the company's actions in the field of social responsibility and its financial performance [3,5],

- the significance of certain aspects of sustainable development for companies of different sectors $[4,6]$,

- the degree of satisfaction of the parties involved, investors in the first place, in the disclosure of social information [2,3],

- the development of non-financial reporting standards $[3,4,7]$ in the interests of the parties involved and with reference to new challenges, COVID-19 pandemic being the first of them, and others.

Most of the studies analyzed show a positive relationship between social responsibility and financial performance $[1,2,3]$. The studies have argued that corporate social responsibility has a positive effect on financial performance by meeting the goals of the stakeholders [3].

There is a growing body of empirical evidence that social capital makes a significant contribution to sustainable development. Social capital refers to the internal social and cultural coherence of a society, the norms and values that govern the interactions between people and the institutions in which they are embedded. The lack of constructive interaction between micro and macro levels can lead to a significant erosion of trust, one of the most important and most widely discussed elements of social capital.

The study of conceptual issues of defining social capital in modern society, its boundaries and impact on modern economic phenomena is presented in the work by Bhandari and Yasunobu [7].

In their research, Vithana et al [8] study 100 firms and analyze the nature, quality and extent of human resource disclosure (HRD) of the UK Financial Times Stock Exchange (FTSE). The findings display that over the past decade, disclosures about human capital have tended to be integrated into the broader concept of disclosure on social, ethical or intellectual capital. The work of Hruska-Tvrdy, Foldynova [9] assesses the pattern of social risks manifestation at present. Drawing on the Keller (2010) research, the authors conduct a comparative analysis of "old" and "new" social risks. The "new" social risks include: "poverty with a job," when a person is forced to accept such low-paid work that he and his family find themselves below the poverty line; unused skills associated with involuntary 
unemployment; impoverishment of retired citizens; inaccessibility or insufficient quality of medical care in certain regions.

Rohde and Rohde [10] emphasize the importance of assessing social risks from the point of view of both the individual and the society. Two essential characteristics for assessing public or social risks are the level of inequality in the distribution of risks between different groups and members of society; and the level of risk that individuals and society as a whole have to deal with.

Despite the growing importance of the impact of social risks and emerging opportunities, there is still very little scientific work dedicated to disclosing the financial consequences of the social risks influence in contrast to the widely discussed issues of the financial consequences of climate risks.

There is no doubt that the importance of studying the risks and opportunities connected with human and social capital became especially evident during the pandemic COVID-19 that exacerbated the existing social problems. The development of the social capital theory and its practical application can become and already is a factor and condition for attracting investment; it also contributes to sustainable development goals. However, this requires additional empirical research in order to develop universally accepted definitions and measurement indicators that will help to clearly separate and quantify the impact of human and social capital on the of society and business development.

\section{Statement of Basic Materials}

The theoretical part of the study was based on the analysis of the human and social capitalrelated topics in the GRI, IR, SASB, standards in order to identify key topics and requirements for their disclosure in financial and non-financial reporting, as well as Literature Review. It allows to identify the main issues and their coverage in academic research in order to develop methods of accounting and disclosing human and social related risks and opportunities in corporate reporting.

The practical part of the study is based on the analysis of 42 financial and 37 non-financial reports (including 23 SDR, 12 IR and 2 CSR) of Russian metallurgical companies for the period 2017-2019. In addition, the interim financial statements of these companies for 2020 were analyzed. This sector of economy was chosen due to the large number of employees, its significant contribution to the gross national product, and the important social impact of the analyzed companies on a wide range of stakeholders: employees, suppliers, customers, local communities.

The study of social disclosures was structured according to two types of reporting financial and non-financial in the context of 10 key aspects highlighted in Table 1.

The hypothesis of the study was as follows: financial statements contain some disclosures of social nature, there is the connection between socially oriented information in companies' financial and non-financial statements; social disclosures presented by most companies in non-financial reporting can be characterized as profound. This hypothesis is based on the previously conducted studies of financial and non-financial reporting in terms of environmental information disclosure, as well as earlier research of the largest Russian companies 'reporting in relation to other relevant disclosure issues.

The results from the analysis of societal information disclosing in the non-financial statements of the largest Russian metallurgical companies are presented in Table 1. 
Table 1. Assessment of the level of social aspects disclosure in non-financial reporting of metallurgical companies Presented as \% of the total number of analyzed reports.

\begin{tabular}{|l|l|l|l|}
\hline Indicators & Mention & $\begin{array}{l}\text { General } \\
\text { disclosures }\end{array}$ & $\begin{array}{l}\text { Full } \\
\text { disclosure }\end{array}$ \\
\hline 1. Health and Safety & - & 16,2 & 83,8 \\
\hline $\begin{array}{l}\text { 2. Employment (structure, movement, terms of } \\
\text { hiring) }\end{array}$ & - & 13,5 & 78,4 \\
\hline 3. Working conditions & - & 27,0 & 70,3 \\
\hline 4. Diversity and equal opportunities & 21,6 & 27,0 & 51,4 \\
\hline 5.Training and career growth & - & 21,6 & 78,4 \\
\hline 6. Social assessment of suppliers & - & 43,2 & 27,0 \\
\hline 7. Health and safety of customers & 8,1 & 29,7 & 48,6 \\
\hline 8. Societal risks & - & 35,1 & 43,2 \\
\hline 9. Remuneration system & - & 21,6 & 64,9 \\
\hline 10.Social investments & - & 8,1 & 35,1 \\
\hline
\end{tabular}

Some conclusions were drawn from the analysis of the research results.

The presence of social disclosures in financial statements

For most of the surveyed companies such disclosures are either absent or isolated - for example, the number of social investments or social obligations is given.

Interconnection between social information in financial and non-financial reporting

There is practically no connection between societal information in financial and nonfinancial reporting, less than $30 \%$ of surveyed companies made general disclosures in nonfinancial reporting, allowing the user to link separate indicators of financial and non-financial reporting.

\section{Completeness of disclosure of social aspects selected for research}

Disclosure status for selected indicators

The Health and Safety indicator is the leader in deep disclosures in non-financial reporting, every analyzed company has paid a lot of attention to it. In the 2020 financial statements this indicator was mentioned in connection with the pandemic COVID-19.

In their non-financial reporting companies provided detailed information on such indicators as "Employment", "Training and education, career growth" and "Working conditions".

Fewer companies made in-depth disclosures on the following indicators: "Social assessment of suppliers", "Social investments", "Social risks", "Customer health and safety", "Diversity and equal opportunities" (presented in the ascending order of disclosure completeness).

General impression of disclosures, including various information, its presentation format and creativity of the material

Almost all companies use tabular and graphic material for illustration purposes, include photographs and other materials that visualize information. A number of companies publish their social action plans and progress reports.

Special prominence should be given to companies' messages on creative events that are not found elsewhere, i.e. companies are looking for innovations in the social sphere, and implement them. Four such companies have been identified.

Less than $10 \%$ of surveyed non-financial reports gave sufficiently detailed information on Covid19 in their 2019 reporting. One of the companies provided this information under the "Events after the reporting period" title, in a manner similar to financial statements.

Significant topics are often described, in most reports these topics are common for all companies, with some exceptions.

Many companies`reports mention charity as well as general anti-corruption disclosures. 
Financial and non-financial disclosures also include information on social risks, but this information is less often complete and well-structured. We believe that in order to identify all existing social risks, work effectively to neutralize them and form risk disclosures adequate for the stakeholders' expectations, it is necessary to first classify social risks according to the most important and relevant features.

In addition to the common risk classifications (e.g. probability, impact magnitude), we recommend using classifications provided in Table 2.

Table 2. Recommended additional social risk classifications to improve corporate disclosures

\begin{tabular}{|c|c|}
\hline Classification attribute & Types of risks \\
\hline Risk sources for the Company & $\begin{array}{l}\text { Management decisions } \\
\text { Externalities } \\
\text { Others }\end{array}$ \\
\hline Types of risks by direction of impact & $\begin{array}{l}\text { On partners } \\
\text { On clients } \\
\text { On society } \\
\text { On the Company }\end{array}$ \\
\hline Risk mitigation opportunity & $\begin{array}{l}\text { Immediate } \\
\text { Nearest } \\
\text { Distant } \\
\text { Absent }\end{array}$ \\
\hline Risk specificity & $\begin{array}{l}\text { Company specific } \\
\text { Common in business } \\
\text { Common in the industry } \\
\text { Unique }\end{array}$ \\
\hline $\begin{array}{l}\text { The presence of an identical risk in the past for the } \\
\text { Company }\end{array}$ & $\begin{array}{l}\text { Yes } \\
\text { Not }\end{array}$ \\
\hline The experience an identical risk mitigation in the past & $\begin{array}{l}\text { Successful } \\
\text { Not successful }\end{array}$ \\
\hline The duration of risk existence for the company & $\begin{array}{l}\text { Short-term } \\
\text { Long-term }\end{array}$ \\
\hline $\begin{array}{l}\text { Expected duration of risk for the company in the } \\
\text { future }\end{array}$ & $\begin{array}{l}\text { Insignificant } \\
\text { Long-term }\end{array}$ \\
\hline Risk significance for the Company & $\begin{array}{l}\text { Priority } \\
\text { Non- priority }\end{array}$ \\
\hline Risk significance for the stakeholders & $\begin{array}{l}\text { Priority } \\
\text { Non- priority }\end{array}$ \\
\hline $\begin{array}{l}\text { The level of responsibility, which assumes the } \\
\text { Company in connection with the risk }\end{array}$ & $\begin{array}{l}\text { High } \\
\text { Moderate } \\
\text { Low }\end{array}$ \\
\hline
\end{tabular}

These classifications can be applied to risks of almost any nature, not just the social risks. In addition, the classifications can be supplemented depending on the company's specifics. In any case, proposed classifications should make social risk information more productive.

\section{Conclusions}

The study carried out on the example of large Russian metallurgical companies makes it possible to characterize the level of social aspects disclosure in financial and non-financial reporting.

In the financial statements, there are very few disclosures that deal particularly with social issues; in non-financial statements the social sphere is presented in sufficient detail, reflecting many important indicators. However, the following issues need to be solving: 
There are no links providing a connection between the data of reporting forms and notes in financial and non-financial statements. There is no way to compare data of social spending in the financial statements and non-financial reporting.

Information in non-financial statements of various companies is generally difficult to perceive because its presentation lacks clarity. Even with the relevant sections present, the information inside is presented with various degrees of detail. It is difficult to understand what was planned in the past 2 or 3 years, and what plans have been fulfilled in the reporting year, what conclusions have been drawn.

The overwhelming majority of companies do not bring forward the relationship between social and financial strategy in their reports.

There is hardly any negative experience reported. It is not typical to point out the mistakes of the strategy and draw conclusions from them. There is no information on the crucial social threats that are commonly found in both the world community and the company itself: threatrisk-measures-result.

The composition of the indicators disclosed in the companies' reports differs, which complicates the process of their comparative analysis.

Our recommendations come from the noted shortcomings, and we propose their gradual elimination, both by the companies and by the developers of standards (financial and nonfinancial) with the participation of all parties involved.

According to the conducted analysis, the quality of information disclosure on human and social capital is growing over time under the influence of investors' expectations and improving standards.

It should be assumed that the solution to the issue of harmonization for financial and nonfinancial social information presupposes the fulfillment of the following conditions.

\section{References}

1. B. Cheng, I. Ioannou, G, Serafeim, Strategic Management Journal, 35, 1 (2014)

2. M. Barnett, R. Salomon, Strategic Management Journal, 27(11), 1101 (2006)

3. G. Clark, A. Feiner, M. Viehs, From the stockholder to the stakeholder. How sustainability can drive financial outperformance, https://arabesque.com/

4. B.A. Amanzolova, N.V Fribus, E.V. Khomenko, Actual problems of electronic instrument engineering (APEIE), 8, 327.

5. A. Amel-Zadeh, G. Serafeim, Why and How Investors Use ESG Information: Evidence from a Global Survey, Harvard Business school, http://www.hbs.edu/

6. O.V. Efimova, O.V., Rozhnova, Journal of Digital Science, 2(1), 67 (2020)

7. H. Bhandari, K., Yasunobu, A Comprehensive Review of the Concept Asian Journal of Social Science, 37(3), 480 (2009)

8. K. Vithana, T. Soobaroyen, C.G, Journal of Business Ethics. Human Resource Disclosures in UK Corporate Annual Reports: To What Extent Do These Reflect Organisational Priorities Towards Labour? https://www.researchgate.net/

9. L. Hruska-Tvrdy, I. Foldynova, New social risks and sustainable development of urban area. https://www.researchgate.net

10. I.M Rohde, M. Rohde, K.I., Journal of Risk and Uncertainty, 51, 2, https://link.springer.com/ 